LAUREN F. PFISTER

\title{
INTRODUCTION: \\ SØREN KIERKEGAARD AND CHINESE PHILOSOPHY
}

Portrayed at times as a troubled literary genius, Søren Aabye Kierkegaard (1813-1855) has nevertheless been characterized by Eric Ziolkoski, in addition to the literary likenesses that the polyphony of his numerous works evokes, to "the 'Danish Socrates' or 'modern Socrates," or even more expansively as "Christianity's Socrates." This historical analogy can be a fruitful way to explore what has proven to be a substantial corpus of translations and multi-faceted secondary literature about Kierkegaard in Anglophone, Hispanophone, and Nipponaphone worlds. ${ }^{2}$ Serving often as an ironic cultural gadfly biting the Danish cultural icons of his day, Kierkegaard adopted a perplexing array of pseudonyms to reveal various perspectives about the features and failures of human selfhood, while simultaneously exploring numerous philosophical, religious, and theological themes. It was a kind of multi-media barrage of perspectives on the midnineteenth century Danish public, a multiform theatrical display of life options, including among them a counter-cultural form of Christianity which Kierkegaard preferred, and all presented in a pre-massmedia age.

Inspiration subsequently drawn by many European intellectuals and philosophers from Kierkegaard's writings links him to many trends in various academic disciplines. Within philosophical realms there are those who claim him as either a precedent or an exemplar for existential, irrationalist, deconstructionist, post-modern, and non-foundationalist philosophical trends. Nevertheless, Kierkegaard's place in the Chinese academy and within Chinese philosophical circles is still being worked out, and has been essentially sidelined for decades within the People's Republic of China.

In spite of some long-term scholarly interest and growing academic discussion of Kierkegaardian studies in Taiwan, Hong Kong, South

LAUREN F. PFISTER, Professor, Religion and Philosophy Department; Director, Centre for Sino-Christian Studies, Hong Kong Baptist University; Founding Fellow of the Hong Kong Academy of the Humanities; Associate Editor, Journal of Chinese Philosophy. Specialties: Qing dynasty philosophy, Ruist-Christian dialogue, hermeneutics. E-mail: feileren@hkbu.edu.hk

Journal of Chinese Philosophy 40:1 (March 2013) 5-8

(C) 2013 Journal of Chinese Philosophy 
Korea, and Japan, there has been far less development of this sort in Mainland China. ${ }^{3}$ One academician from the Chinese Academy of Social Sciences in Beijing, Wang Qi, has documented the fact that in Mainland China there have only been very limited Chinese translations of Kierkegaard's works, with only one piece having been done by a Chinese scholar competent in Danish and so able to render Fear and Trembling in 1994 from the standard text in the original language. ${ }^{4}$ Even though this account from Mainland China has not presented a complete picture of all the works dealing with Kierkegaard in the Chinese language medium within cultural China, it is nevertheless generally still the case that studies of Kierkegaard have not become a prominent dimension of even "Western" philosophical studies within Chinese philosophical circles. One further sign of the relatively inchoate state of academic investigations into Kierkegaard's works is that even during the past two and a half decades there are still as many as four ways of rendering his name into Chinese within published translations and studies of his works. ${ }^{5}$

As William Ng has confirmed, not even one quarter of all histories of "Western philosophy" produced in Chinese during the past century have included sections describing Kierkegaard's philosophical contributions. ${ }^{6}$ Among those who have translated and studied Kierkegaard's writings, perhaps the most prolific is the Taiwanese scholar Chen Chun Hui 陳俊輝, who within a period of seven years (1987-1994) produced nine volumes published in Taipei, none of which were mentioned in Wang Qi's article. These included five volumes of translated quotations arranged thematically, and in addition a biography on Kierkegaard as well as three other studies linking Kierkegaard's writings to trends in the history of philosophy, existentialism, and hermeneutics. ${ }^{7}$ While this serves as a counter to the impression that there has been little interest in Kierkegaard's works in cultural China, there are still some significant shortcomings. For example, there is hardly any study in cultural China exploring various comparative philosophical and comparative cultural research projects where Kierkegaard's works have been involved.

With the arrival of the 200th anniversary of the birth of Søren Kierkegaard in the year 2013, the Journal of Chinese Philosophy has sought to ignite a new interest in the Danish philosopher by offering articles revealing new developments in scholarly accounts of Kierkegaard's philosophical corpus as well as a wide-ranging comparative philosophical Sino-European engagement with a number of the major themes in Kierkegaard's Christian and pseudonymous works. In fact, a wide range of international conferences and symposia focusing on the legacy of Kierkegaard's writings and influences are being held during this year, but it is still a rare occurrence to have 
themes which link up Kierkegaard's complicated corpus-fully aware of the authorial problems which his poly-pseudonymous works have created - with parallel streams of thought and life in Chinese cultural contexts. ${ }^{8}$ We are sure that this issue contributes to a new confluence of these philosophical streams, and hope to encourage more creative cross-cultural engagements through the essays found collected here.

We believe that this set of articles may serve as a comparative philosophical beacon leading to a new set of philosophical questions which deserve our attention. Through these articles we have engaged Kierkegaardian themes in Chinese philosophical contexts, all of which are responsive to twenty-first-century cultural issues in cultural China. As Chinese philosophers continue to move forward on the world stage of philosophical research and scholarly interaction, their engagement with Kierkegaard should grow as well, for it promises many new frontiers for comparative philosophical engagement.

HONG KONG BAPTIST UNIVERSITY Hong Kong, China

\section{ENDNOTES}

1. Quoting from Eric Ziolkowski, The Literary Kierkegaard (Evanston: Northwestern University Press, 2011), 56. These characterizations are Ziolkowski's catalog of previous assessments of Kierkegaard by other earlier scholars of his works.

2. See articles on Australia, Canada, and the United States by William McDonald, Abraham H. Khan, and Lee C. Barrett, respectively, one on Japan by Satoshi Nakazato, as well as two articles on Mexico and "Hispanophone South America" by Leticia Valadez and Patricia Carina Dip, respectively, in Kierkegaard's Reception-Tome III: The Near East, Asia, Australia and the Americas, ed. Jon Stewart (Farnham: Ashgate Publishing Limited, 2009).

3. See relevant articles in Jon Stewart, ed., Kierkegaard's Reception-Tome III: The Near East, Asia, Australia and the Americas. Though there is not an article in this volume focused on either Taiwanese or Hong Kong reception, the Korean article involves a bibliography including translations of Kierkegaard's works in and of itself that go beyond two pages (145-7), while the bibliography of renderings and secondary literature in Japanese on Kierkegaard extends to 18 pages (155-73). Details about Taiwan and Hong Kong have been gleaned from an essay-in-process written by William Ng Yau Nang (Wu Youneng 吳有能) in Chinese and given the English title, “The Reception of Søren Kierkegaard in Chinese Communities: An Intellectual History."

4. See Wang Qi, "China: The Chinese Reception of Kierkegaard," in Kierkegaard's Reception-Tome III, ed. Jon Stewart, 103-23. The scholar mentioned is Liu Ji 劉繼 (121). Notably, the total length of the bibliographic section of this article, including both primary and secondary sources, does not extend beyond three printed pages.

5. There have been three renderings of Kierkegaard's name in Mainland China, all of which offer a rather cumbersome phonetic presentation of his family name, using almost the same sounds, but different characters: the first two are pronounced as Ke'er kaiguoer 克爾凱郭爾 and 克爾愷郭爾, while the third is pronounced as Ke'er kaige'er 克爾凱戈爾. The fourth option is perhaps less commonly found, though it is becoming more prevalent, because it has been significantly sinified, so that it sounds better to a Chinese reader: Qi Keguo 齊克果. This name first appeared as the author of a 
translation of The Seducer's Diary by Meng Xiangsen 孟祥森 in 1971. These details are found in the draft article written by my colleague Dr. William Ng Yau Nang, already mentioned above.

6. Cited in the essay by Dr. William Ng Yau Nang already mentioned above. Out of 110 such works, only twenty-seven mentioned and/or included a section devoted to Kierkegaard.

7. Documented in William Ng Yau Nang's article.

8. Here we would want to note that the Centre for Sino-Christian Studies at the Hong Kong Baptist University, in the hope of adding to this wave of new cross-cultural philosophical and cultural investigations, is hosting a major international conference on the theme of "Søren Kierkegaard and Chinese Culture" during May 21-23, 2013. 